\title{
Critical Thinking among Al-Balqa Applied University Students
}

\author{
Salem Ali Salem Algharaibeh ${ }^{1, *}$, Rana Thani ALmomani ${ }^{2}$ \\ ${ }^{1}$ Department of Educational Sciences, Ajloun University College, Al-Balqa Applied University, Jordan \\ ${ }^{2}$ Ministry of Education, Jordan
}

Received April 26, 2020; Revised July 2, 2020; Accepted July 20, 2020

\section{Cite This Paper in the following Citation Styles}

(a): [1] Salem Ali Salem Algharaibeh, Rana Thani ALmomani , "Critical Thinking among Al-Balqa Applied University Students," Universal Journal of Educational Research, Vol. 8, No. 9, pp. 3834 - 3841, 2020. DOI: 10.13189/ujer.2020.080906.

(b): Salem Ali Salem Algharaibeh, Rana Thani ALmomani (2020). Critical Thinking among Al-Balqa Applied University Students. Universal Journal of Educational Research, 8(9), 3834 - 3841. DOI: 10.13189/ujer.2020.080906.

Copyright@2020 by authors, all rights reserved. Authors agree that this article remains permanently open access under the terms of the Creative Commons Attribution License 4.0 International License

\begin{abstract}
Critical thinking is a central part of our daily life. It has great importance in immunizing the individual against the vast amount of information, events, and situations that the individual deals with and faces. This study aimed at identifying differences in critical thinking according to different variables. The variables were specializations (scientific, literary), gender (male, female), the Grade Point Average (GPA) and the scores of Jordanian high school national exam (Tawjiji) to predict critical thinking skills. This quantitative study used the descriptive approach by applying Watson's and Glasser's [16] critical thinking appraisal short form transferred to Arabic by Alotaibi [7]. This study was applied to a sample comprising (216) students from Ajloun University College, affiliated with Al-Balqa Applied University, students in Jordan. The results indicated that the study sample had high levels of critical thinking of sub- skills and a high level in critical thinking as for the total scores. There were statistically significant differences in all critical thinking of sub- skills according to specializations in favour of the scientific stream. Besides, there were statistically significant differences in all critical thinking skills according to gender in favour of males. Also, critical thinking could be predicted by the degree of the national examination for high school in Jordan (Tawjiji) but not by Grade Point Average (GPA). The differences in critical thinking between students of scientific streams and literary ones may refer to the difference in school curricula. The scientific courses focus on critical thinking skills more than literary ones. Therefore, it was important to include critical
\end{abstract}

thinking skills in school curricula since critical thinking skills are very important in an individual's success both in study and life.

Keywords Critical Thinking, National Exam for High School in Jordan (Tawjiji), Undergraduate Students, AL-Balqa Applied University, Grade Point Average (GPA)

\section{Introduction}

Learning and teaching thinking skills became a requirement for all students. It is not limited to the most intelligent and distinguished, but includes those who have less intelligence and excellence. They can learn basic and senior thinking skills when they have effective educational conditions [1].

Critical thinking is a central part of our daily life. It has great importance in immunizing the individual against the vast amount of information, events, and situations that the individual deals with and faces. The individual can be a judge of those positions, as the validity of judgment determines the extent of life success. Hence, the individual possession of critical thinking skills that enables the individual to properly diagnose and deal with these problems [2].

Critical thinking implies critically asking questions about the problems [3]. From this perspective, critical 
thinking helps the individual to refine the information as it enables the individual to assess the extent of its validity. Also, it enables the individual to discover its fallacies, and verify the extent to which the evidence relates to the subject related to it. And thus, the critical thinker is aware of how to reach the correct judgment [2].

Critical thinking is rational and contemplative thinking that focuses on deciding about belief or performance [4]. It requires at least two types of judgment. The first relates to the reasonableness of the foundations on which beliefs or judgments are based on. The second relates to how these foundations come into belief, requiring the use of many skills such as deduction, induction, and evaluation [5].

It is important to point out that a common misunderstanding about critical thinking is that a critical thinker is interested in revealing weaknesses and shortcomings and identifying negatives and faults in the addressed topic. However, the truth is that a critical thinker also tends to clarity and accuracy and is not limited to revealing only the negative aspects [6] [7].

Brookfield [8] defined critical thinking as cognitive activities including logical reasoning, an examination of discussions, and learn about assumptions. Johnson and Johnson [9] defined it as the use of reasoning rules and avoiding common errors in judgment. Udall, and Daniels [10] defined critical thinking as the ability to verify and correct a phenomenon and to base on specific criteria. Also, it was defined as a self-organized judgment that aimed at interpretation, analysis, evaluation, and conclusion. Besides, they were interested in explaining considerations related to evidence and concepts, methods, and proofs [11]. Critical thinking was defined also as a reflection thinking in which awareness of the steps of thinking appeared to reach to conclusions and decisions [12]. Moore and Pack [13] also defined critical thinking as a form of thinking that the deliberative process consisted of deciding what the individual accepted or rejected. It postponed the judgment on his or her claims with a degree of confidence in his or her acceptance or rejection process.

Several skills have been put in place for critical thinking. Ennis [14] [15]; [4] assumed there were ten critical thinking skills. They were focus and analysis of arguments, good questions and definition terminology, judging definitions, identifying assumptions and judging information credibility, observation and evaluating reports of observations, conclusion, discrimination and outcome judgment derived from induction processes, value judgment, reasoning, and complementarity.

There are many classifications of critical thinking skills of which Watson's and Glaser's Model is the most famous one [16]. It indicated that critical thinking is measured through five sub-skills: Inference, Recognition of assumptions, deduction, interpretation, and evaluation of arguments.

Critical thinking has criteria that are intended to be those specifications agreed upon by researchers in the field of thinking. They are taken mainly in judging the type of inferential or evaluative thinking that an individual uses when treating a problem or a topic [17].

Several studies have dealt with critical thinking with different variables, such as metacognitive skills [18], general reasoning in mathematics [19], cognitive motivation [20], cognitive load [21]. Other variables include building a measure of critical thinking [22], as well as adapting Watson's and Glaser's critical Thinking Appraisal Short Form to the Arabic environment [7], and others.

The high level of critical thinking within the educational institution is an evidence of the high quality of education index within that institution. This result was indicated by Grozdanka, Aleksandar and Aleksandra [23] in a study aimed at identifying critical thinking as a predictor of the quality of education among university students. The results found a statistically significant relationship between critical thinking and the quality of education since critical thinking was a strong predictor of the quality of education.

Jenkins [24] pointed out that critical thinking is essential for a future school. The formation of minds and making them critical are the aims of education [25]. Individuals must be able to criticize and distinguish between truth and belief. Critical thinking skills are an important component of school, university, and education [26].

McBride (cited in [27]) emphasized that the most important objective of higher education is to develop and improve critical thinking skills. Alter and Egan [28] stated that knowing scientific methods does not guarantee that students will apply and practice critical thinking. Critical thinking is the criterion of success [29] and it is a good predictor of success [30].

Algharaibeh [6] pointed out the importance of developing the capabilities of critical thinking for any society. It gives appropriate opportunities for the growth of intellectual energies that is a very important issue for any society. Many researchers focused on the importance of teaching critical thinking and developing its abilities among students. That is because it contributes to building the intellectual personality capable of facing the requirements of the rapid change that we live in. Also, it develops the ability to solve problems that we face in various fields of life, including education. The primary objective of education is no longer the accumulation of knowledge [6] [7] [21] [29].

Critical thinking skills are very needed in the 21st-century life, so studying students' learning outcomes is needed as a criterion of learning. The Tawjihi exam is the last academic stage before a student enters university. The student's achievement at the university is to be related to the achievement in the Tawjihi. And both of them are supposed to be related to critical thinking. Hence, it is important to know the level of critical thinking among Tawjihi and university students and its relationship to their 
academic achievement. It is very important to know if Tawjihi and GPA can predict critical thinking among the students. And knowing the level of critical thinking among Tawjihi and university students enables us to judge the effectiveness of the teaching process. Also, it enables us to judge the effectiveness of curriculum activities and scientific content that contribute to the development of critical thinking.

Accordingly, the current study aimed at identifying the levels of students' critical thinking and the differences among them according to different variables. The variables were specializations (Scientific, Literary), gender (male, female), the predictive ability of Grade Point Average (GPA), and the degree of the national examination for high school in Jordan (Tawjiji).

\section{Research Questions:}

The current study tried to answer the following questions:

1. Are there significant differences in critical thinking and its sub-skills according to students' specialization (scientific, literary)?

2. Are there significant differences in critical thinking and its Sub- skills according to students' gender (females, males)?

3. Could Grade Point Average (GPA) and the degree of National Examination for High School in Jordan (Tawjiji) predict critical thinking significantly?

\section{Research Method}

\subsection{Methodology}

This study relied on a descriptive approach design to explore the differences in critical thinking according to different variables. The variables were students' specialization (scientific, literary) and gender (male, female), examining the ability of Grade Point Average (GPA). And the degree of National Examination for High School in Jordan (Tawjiji) in Predicting Critical Thinking skills among the study sample was the last variable.

\subsection{Participants}

The population of this study was Al-Balqa Applied University students. The sample consisted of (216) psychological counselling students who were randomly selected (simple) from Ajloun college in the first semester of the academic year 2019, 2020. According to gender, 125 (58\%) of the participants were females, and 91 (42\%) males. And according to speciality, 152 (70\%) of the participants were from the scientific stream and 64 (30\%) were from the literary one.

\subsection{Study Instrument}

Critical Thinking Appraisal Short Form Test (W-GCTA) [16] was translated to Arabic by Alotaibi [7] who conducted it to the study sample to evaluate critical thinking. Watson's- Glaser's Test evaluates a candidate's critical thinking ability in five areas: inferences $=7$ items, assumptions $=8$ items, deductions $=9$ items, interpretations $=7$ items and evaluation of arguments $=9$ items. There are five different types of questions in Watson's -Glaser's Test. Most people complete the Watson's- Glaser's Test within 50 minutes (approximately 10 minutes per sub-test). Test administrators normally allow candidates one hour to complete the test. The examinee gets one mark for every correct answer and zero for the wrong one [16].

\subsubsection{Validity}

Confirmatory factor analysis was conducted to the model of total one latent trait (critical thinking) of 5 sub-scales which were analysed by using the maximum likelihood method. Univariate normality hold for all sub-scales, multivariate normality was examined using Mardia's coefficient in Amos, where it has an acceptable critical ratio value (less than 5). Multivariate outliers checked using Mahalanobis distance ( $\mathrm{p} 1$ values $<0.001$ represent serious out lier) [31]. Then Amos 23 used to calculate model fit indices which shown in table (1).

Table 1 showed that all goodness of fit indices had acceptable high values which indicated that the data were suitable for the model of W-GCTA well.

Table 1. The goodness of fit indices for W-GCTA

\begin{tabular}{|c|c|c|c|c|c|c|c|}
\hline$\chi^{2}$ & CMIN/DF & IFI & CFI & NFI & AGFI & GFI & RMSEA \\
\hline & 1.607 & 0.997 & 0.997 & 0.992 & 0.956 & 0.988 & 0.053 \\
\hline
\end{tabular}


Table 2. Pearson Correlation Coefficients between item, dimension, dimensions' total scores for critical thinking test

\begin{tabular}{|c|c|c|c|c|c|c|c|c|c|}
\hline \multicolumn{2}{|c|}{ Inference } & \multicolumn{2}{|c|}{$\begin{array}{c}\text { Recognition of } \\
\text { Assumptions }\end{array}$} & \multicolumn{2}{|c|}{ Deduction } & \multicolumn{2}{|c|}{ Interpretation } & \multicolumn{2}{|c|}{ Evaluation of Arguments } \\
\hline $\begin{array}{c}\text { Item } \\
\text { no. }\end{array}$ & Correlation & $\begin{array}{c}\text { Item } \\
\text { no. }\end{array}$ & Correlation & $\begin{array}{c}\text { Item } \\
\text { no. }\end{array}$ & Correlation & $\begin{array}{c}\text { Item } \\
\text { no. }\end{array}$ & Correlation & $\begin{array}{c}\text { Item } \\
\text { no. }\end{array}$ & Correlation \\
\hline 1 & $0.53 * *$ & 8 & $0.72 * *$ & 16 & $0.35 * *$ & 25 & $0.55^{* *}$ & 32 & $0.40 * *$ \\
\hline 2 & $0.23 * *$ & 9 & $0.52 * *$ & 17 & $0.67 * *$ & 26 & $0.59 * *$ & 33 & $0.41 * *$ \\
\hline 3 & $0.66^{* *}$ & 10 & $0.38 * *$ & 18 & $0.61^{* *}$ & 27 & $0.51^{* *}$ & 34 & $0.68^{* *}$ \\
\hline 4 & $0.67 * *$ & 11 & $0.20^{* *}$ & 19 & $0.28 * *$ & 28 & $0.50 * *$ & 35 & $0.64^{* *}$ \\
\hline 5 & $0.64^{* *}$ & 12 & $0.97^{* *}$ & 20 & $0.82 * *$ & 29 & $0.72 * *$ & 36 & $0.67 * *$ \\
\hline 6 & $0.52 * *$ & 13 & $0.46^{* *}$ & 21 & $0.38 * *$ & 30 & $0.65^{* *}$ & 37 & $0.39 * *$ \\
\hline \multirow[t]{3}{*}{7} & $0.82 * *$ & 14 & $0.46^{* *}$ & 22 & $0.37 * *$ & 31 & $0.31^{* *}$ & 38 & $0.16^{*}$ \\
\hline & & 15 & $0.49^{* *}$ & 23 & $0.85^{* *}$ & & & 39 & $0.57 * *$ \\
\hline & & & & 24 & $0.14^{*}$ & & & 40 & $0.39 * *$ \\
\hline $\begin{array}{l}\text { Total } \\
\text { score }\end{array}$ & $0.90 * *$ & $\begin{array}{l}\text { Total } \\
\text { score }\end{array}$ & $0.86^{* *}$ & $\begin{array}{l}\text { Total } \\
\text { score }\end{array}$ & $0.83^{* *}$ & $\begin{array}{l}\text { Total } \\
\text { score }\end{array}$ & $0.92 * *$ & $\begin{array}{l}\text { Total } \\
\text { score }\end{array}$ & $0.86^{* *}$ \\
\hline
\end{tabular}

Then Pearson correlation coefficients for items, dimension and dimensions' total scores were calculated as shown in Tables (2).

As shown in table 2, all items correlated significantly with their total ability score. As well, each ability score correlated significantly with the total score of W-GCTA, indicating a good internal consistency.

\subsubsection{Reliability}

The reliability of the evaluated test, using the Alpha Coefficient for each ability and the whole test, showed that the critical thinking test had acceptable degrees of reliability as follows.

Table 3. Reliability coefficients (alpha) for the Critical Thinking Test

\begin{tabular}{ccc}
\hline Measure & $\begin{array}{c}\text { Alpha Coefficient } \\
\text { current study }\end{array}$ & $\begin{array}{c}\text { Al Otaibi } \\
\mathbf{( 2 0 1 2 )}\end{array}$ \\
\hline Inference & 0.69 & 0.70 \\
\hline $\begin{array}{c}\text { Recognition of } \\
\text { Assumptions }\end{array}$ & 0.60 & 0.83 \\
\hline Deduction & 0.70 & 0.55 \\
\hline Interpretation & 0.63 & 0.78 \\
\hline Evaluation of Arguments & 0.62 & 0.67 \\
\hline Total Critical Thinking & 0.90 & 0.80 \\
\hline
\end{tabular}

\subsection{Research Procedure}

Critical Thinking Appraisal Short Form was administered on the study participants on a voluntary basis which took approximately 50 minutes to be completed.

\section{Results and Discussion}

To determine Critical thinking skills (Inference, Recognition of Assumptions, Deduction, Interpretation, and Evaluation of Arguments) among Al-Balqa Applied University students, means and standard deviations were calculated. The calculation was built on Watson's and Glaser's Critical Thinking Appraisal Short Form Test used in this study as shown in table (4).

Table 4. Descriptive Statistics of the study sample performance on Critical Thinking Test

\begin{tabular}{cccc}
\hline Critical Thinking Skill & N & Mean & Std. Deviation \\
\hline Inference & 216 & 4.38 & 2.19 \\
\hline Recognition of Assumptions & 216 & 5.84 & 1.61 \\
\hline Deduction & 216 & 7.10 & 1.81 \\
\hline Interpretation & 216 & 4.94 & 1.66 \\
\hline Evaluation of Arguments & 216 & 7.60 & 1.54 \\
\hline Total critical thinking & 216 & 29.41 & 7.36 \\
\hline
\end{tabular}

Table 4 shows that the highest mean belonged to the skill of Evaluation of Arguments (mean $=7.60, \mathrm{Sd}=1.54$ ). It was also observed that Deduction came in the second rank between critical thinking skills (mean $=7.10$, $\mathrm{sd}=1.81$ ). Then, Recognition of Assumptions (mean = 5.84, sd=1.61), then Interpretation (mean $=4.94$, sd=1.66). And the lowest mean value was for Inference skill (mean = 4.38, sd=2.19). The whole test mean was 29.41 with Sd equals to 7.36.

To examine the differences in critical thinking and its sub-skills according to students' specialization (scientific and literary), an independent sample $t$-test was conducted as shown in table (5).

The results shown in table 5 indicated that there were significant differences in all critical thinking skills and the total score between the two groups. We can notice that there were significant differences in inference $(t=6.63$, $\mathrm{p}$-value $=0.000)$. This result suggested that the individuals in the scientific group $(\mathrm{m}=4.86$; $\mathrm{sd}=2.12)$ have higher levels of inference than the individuals in the literary group $(\mathrm{m}=2.89$; $\mathrm{sd}=1.66)$.

Table 5 also shows that there were significant differences in Recognition of Assumptions, $(\mathrm{t}=7.03$, $\mathrm{p}$-value $=0.000)$. This means that the individuals in the scientific group $(\mathrm{m}=6.29$; $\mathrm{sd}=1.53$ ) have higher levels of Recognition of Assumptions than the individuals in the literary group $(m=4.77$; $s d=1.24)$.

The scientific group also has a higher level $(\mathrm{m}=7.67$; sd $=1.73)$ than the literary group $(\mathrm{m}=5.63$; $\mathrm{sd}=1.03)$ of deduction $(\mathrm{t}=8.79$, $\mathrm{p}$-value $=0.000)$. 
Table 5. Independent Sample T-Tests between students scientific and literary on critical thinking test

\begin{tabular}{|c|c|c|c|c|c|c|c|}
\hline & Speciality & Mean & Std. Deviation & $\mathbf{N}$ & df & $\mathbf{t}$ & Sig. (2-tailed) \\
\hline \multirow{2}{*}{ Inference } & Scientific & 4.86 & 2.12 & 152 & \multirow[b]{2}{*}{214} & \multirow{2}{*}{6.63} & \multirow{2}{*}{.000} \\
\hline & Literary & 2.89 & 1.66 & 64 & & & \\
\hline \multirow{2}{*}{ Recognition of Assumptions } & Scientific & 6.29 & 1.53 & 152 & \multirow{2}{*}{214} & \multirow{2}{*}{7.03} & \multirow{2}{*}{.000} \\
\hline & Literary & 4.77 & 1.24 & 64 & & & \\
\hline \multirow{2}{*}{ Deduction } & Scientific & 7.67 & 1.73 & 152 & \multirow{2}{*}{214} & \multirow{2}{*}{8.79} & \multirow{2}{*}{.000} \\
\hline & Literary & 5.63 & 1.03 & 64 & & & \\
\hline \multirow{2}{*}{ Interpretation } & Scientific & 5.37 & 1.65 & 152 & \multirow{2}{*}{214} & \multirow{2}{*}{6.45} & \multirow{2}{*}{.000} \\
\hline & Literary & 3.91 & 1.17 & 64 & & & \\
\hline \multirow{2}{*}{ Evaluation of Arguments } & Scientific & 8.05 & 1.36 & 152 & \multirow{2}{*}{214} & \multirow{2}{*}{7.40} & \multirow{2}{*}{.000} \\
\hline & Literary & 6.53 & 1.44 & 64 & & & \\
\hline \multirow{2}{*}{ Total Critical Thinking } & Scientific & 31.81 & 7.15 & 152 & \multirow{2}{*}{214} & \multirow{2}{*}{8.51} & \multirow{2}{*}{.000} \\
\hline & Literary & 23.72 & 3.95 & 64 & & & \\
\hline
\end{tabular}

Table 6. Independent Sample T-Tests between males' and females' responses to critical thinking test

\begin{tabular}{|c|c|c|c|c|c|c|c|}
\hline & Gender & Mean & Std. Deviation & $\mathbf{N}$ & df & $\mathbf{t}$ & Sig. (2-tailed) \\
\hline \multirow{2}{*}{ Inference } & Female & 3.40 & 1.99 & 125 & \multirow{2}{*}{214} & \multirow{2}{*}{-7.92} & \multirow{2}{*}{.000} \\
\hline & Male & 5.50 & 1.83 & 91 & & & \\
\hline \multirow{2}{*}{ Recognition of Assumptions } & Female & 5.12 & 1.54 & 125 & \multirow{2}{*}{214} & \multirow{2}{*}{-8.99} & \multirow{2}{*}{.000} \\
\hline & Male & 6.82 & 1.40 & 91 & & & \\
\hline \multirow{2}{*}{ Deduction } & Female & 5.99 & 1.40 & 125 & \multirow{2}{*}{214} & \multirow{2}{*}{-14.04} & \multirow{2}{*}{.000} \\
\hline & Mail & 8.53 & 1.21 & 91 & & & \\
\hline \multirow{2}{*}{ Interpretation } & Female & 4.10 & 1.42 & 125 & \multirow{2}{*}{214} & \multirow{2}{*}{-11.65} & \multirow{2}{*}{.000} \\
\hline & Male & 6.14 & 1.12 & 91 & & & \\
\hline \multirow{2}{*}{ Evaluation of Arguments } & Female & 6.96 & 1.39 & 125 & \multirow{2}{*}{214} & \multirow{2}{*}{-8.20} & \multirow{2}{*}{.000} \\
\hline & Male & 8.48 & 1.29 & 91 & & & \\
\hline \multirow{2}{*}{ Total Critical Thinking } & Female & 25.42 & 5.51 & 125 & \multirow{2}{*}{214} & \multirow{2}{*}{-12.10} & \multirow{2}{*}{.000} \\
\hline & Male & 34.89 & 5.94 & 91 & & & \\
\hline
\end{tabular}

According to interpretation, the results shown that there were significant differences between the two groups. The individuals in the scientific group $(\mathrm{m}=5.37$; sd $=1.65)$ have higher levels of interpretation than the ones in the literary group $(\mathrm{m}=3.91$; $\mathrm{sd}=1.17),(\mathrm{t}=6.45$, $\mathrm{p}$-value $=$ $0.000)$.

Table 5 also shows that there were significant differences in Evaluation of Arguments, $(t=7.40$, p-value $=0.000$ ). This means that the individuals in the scientific group $(\mathrm{m}=8.05$; sd $=1.36)$ have higher levels of Evaluation of Arguments than the individuals in the literary group $(\mathrm{m}=6.53$; $\mathrm{sd}=1.44)$.

For the total critical thinking score, the results show that there were significant differences, $(\mathrm{t}=8.51, \mathrm{p}$-value $=$ 0.000 ). This means that the individuals in the scientific group $(\mathrm{m}=31.81$; $\mathrm{sd}=7.15)$ have higher levels of critical thinking than the individuals in the literary group $(\mathrm{m}=$ 23.72; sd = 3.95).

To examine the differences in critical thinking and the sub-skills between the two groups (females and males), an Independent Sample T-Test was conducted as shown in table (6).

Results in table 6 indicated that there were significant differences in all critical thinking skills and the total score according to gender. We can notice that there were significant differences in inference $(\mathrm{t}=-7.92$, $\mathrm{p}$-value $=$ $0.000)$. This result suggested that males $(\mathrm{m}=5.50$; $\mathrm{sd}=$
1.83) have higher levels of inference than females $(\mathrm{m}=$ 3.40; sd = 1.99)

Table 6 also shows that there were significant differences in Recognition of Assumptions, $(t=-8.99$, $\mathrm{p}$-value $=0.000)$. This means that males $(\mathrm{m}=6.82$; $\mathrm{sd}=$ 1.40) have higher levels of Recognition of Assumptions than females $(\mathrm{m}=5.12$; $\mathrm{sd}=1.54)$. Males also had a higher level $(\mathrm{m}=8.53$; $\mathrm{sd}=1.21)$ than the females group $(\mathrm{m}=$ 5.99 ; $\mathrm{sd}=1.40)$ of deduction $(\mathrm{t}=-14.04$, $\mathrm{p}$-value $=0.000)$.

Considering interpretation, the results show that there were significant differences between the two groups. The male group $(m=6.14$; $\mathrm{sd}=1.12)$ has higher levels of interpretation than the female's $(\mathrm{m}=4.10$; $\mathrm{sd}=1.42)$, $(\mathrm{t}=$ -11.65, p-value $=0.000$ ).

Table 6 also showed that there were significant differences in Evaluation of Arguments, $(t=-8.20$, $p$-value $=0.000)$. This means that the male group $(\mathrm{m}=8.48$; $\mathrm{sd}=$ 1.29) has higher levels of Evaluation of Arguments than the female's $(m=6.96$; $s d=1.39)$.

And concerning the total critical thinking score, the results show that there were significant differences, $(t=$ -12.10 , p-value $=0.000$ ). This means that the male group $(\mathrm{m}=34.89$; $\mathrm{sd}=5.94)$ has higher levels of critical thinking than the female's $(m=25.42$; $s d=5.51)$.

The Grade Point Average (GPA) and the degree of the national examination for high school in Jordan (Tawjiji) were examined to predict critical thinking ability. A 
multiple regression analysis was performed using the enter?? method to determine the independent variables (GPA and Tawjihi) to predict the dependent variable (Critical Thinking) as in table 7.

Table 7. Results of the analysis of variance for the regression model

\begin{tabular}{ccccccc}
\hline Model & $\begin{array}{c}\text { Sum of } \\
\text { Squares }\end{array}$ & Df & $\begin{array}{c}\text { Mean } \\
\text { Square }\end{array}$ & F & Sig. & $\mathbf{R}^{2}$ \\
\hline Regression & 793.308 & 2 & 396.654 & 7.780 & 0.001 & \\
\hline Residual & 10859.021 & 213 & 50.981 & & & 0.242 \\
\hline Total & 11652.329 & 215 & & & & \\
\hline
\end{tabular}

Table 7 showed that the total regression model succeeded in predicting critical thinking significantly $(\mathrm{F}=$ 7.780), and the value of the explained variable of the independent variables (GPA and Tawjihi) was $\mathrm{R}^{2}=0.242$.

Table 8 showed the regression coefficients of the regression model and its statistical significance.

Table 8. Multiple regression analysis for the national exam for high school (Tawjihi) and university Grade Point Average (GPA) in predicting critical thinking

\begin{tabular}{cccccc}
\hline Variable & $\mathbf{B}$ & $\mathbf{B}$ & $\mathbf{t}$ & Sig. & $\mathbf{R}^{2}$ \\
\hline Constant & 9.828 & ---- & 1.965 & 0.051 & \\
\hline GPA* $^{*}$ & 0.038 & 0.035 & 0.526 & 0.599 & 0.242 \\
\hline Tawjihi** & 0.268 & 0.259 & 3.913 & 0.000 &
\end{tabular}

* Grade Point Average.

**The national examination for high school in Jordan.

From Table 8, it is clear that Tawjihi (the national examination for high school in Jordan) can predict critical thinking scores among Al-Balqa Applied University students significantly $(\beta=0.259)$. Meanwhile, the grade points average (GPA) was unable to predict critical thinking. Accordingly, the regression equation can be formulated as follows:

Raw regression equation:

- $\quad$ Critical Thinking $=9.828+0.268$ (Tawjihi)

Standard regression equation:

- $\quad$ Critical Thinking $=0.259$ (Tawjihi)

The current results are consistent with many studies' results [19] [7]. They have found that students of the scientific stream have higher levels of critical thinking than the students of the literary one. The differences in the sample's average scores, regarding the critical thinking skills and overall degree of critical thinking, went for the benefit of students of the scientific stream. It is because that the content of the study subjects was studied by students of science majors. And for the tests and tasks involved, they require the use of higher mental skills such as analysis, interpretation, and conclusion. Examining the evidence and other mental processes, that are catalysts for critical thinking, its various skills, and the curricula taught by students of scientific disciplines, require experimentation of different solutions. The solutions will be used to solve the problems facing them during their learning. The researcher explains that the scientific-stream students studied more difficult courses than the ones studied by literary- discipline students, depending on minimum mental skills such as remembering. This pushes students of scientific disciplines to practice critical thinking more than students of literary colleges, and this practice in itself is training on critical thinking, and because training on any skill leads to improving the level of this skill, it is expected that this training will be a fundamental reason for students in Scientific disciplines to own a high level of critical thinking skills because of practice and training.

The researcher also believes that this result indicates that the relationship is close between the type of study (scientific, literary) and critical thinking level, and these results are normal because students with scientific specialties can use mental skills more than others, they are more intelligent inferentially to their treatment and training in scientific subjects, and they need to use higher mental processes such as reasoning, analysis, synthesis, and this can give them the ability to use critical thinking skills.

Also, students of the scientific stream in the general secondary certificate tend to employ logical scientific thinking in their thinking and in their studies in high school. Besides, brain research indicates that such students are from the left brain control tend to activate abstract logical thinking, step-by-step thinking, and convergent thinking. Since the left brain represents the essence of logical reasoning, therefore, logical reasoning is criticism-based thinking.

As for the differences between males and females in critical thinking, the result of the current study matched with the result of Almansour's [19] study. Almansour's study indicated the superiority of males over females in critical thinking. However, it differed with Almohadin [20] and Aldabbas [18] studies which concluded that there were no significant differences in critical thinking due to gender.

The superiority of males over females in critical thinking can be explained by brain control in both males and females as males have left-brain control. Critical thinking is one of the functions of the left half of the brain. Thus, this may be the most important reason for males' superiority over females in critical thinking. The left brain represents the essence of logical reasoning which is, in turn, criticism-based thinking.

The result of the current study indicated that students' degrees at the National Examination for high school in Jordan (Tawjihi) statistically predict the level of critical thinking among Al-Balqa Applied University students. However, the Grade Point Average (GPA) at the university cannot predict critical thinking significantly. This result varies with the results of Mare'i and Nawfal [32].

The researcher can attribute this result to school curricula in high school in Jordan as it is formulated and designed to encourage critical thinking. And the high school examination is a standardized test that is prepared by the Ministry of Education scientifically to get good 
degree of reliability and validity. It is considered a crucial test in determining the path of the student at the university and choosing the specialization that he or she wants. This makes students pay great attention to obtain a high rate and this may be reflected on the level of critical thinking they have.

As for the inability of the Grade Point Average (GPA) to predict critical thinking, it may refer to university examinations which are less elaborate and weaker than the National Examination for high school (Tawjihi). University examinations are prepared by university professors individually who are not be at a high degree of workmanship which may be marred by some design weakness. Hence, this makes it unable to predict the level of critical thinking among students.

\section{Conclusions and Recommendations}

This paper showed that there were significant statistical differences in all critical thinking abilities because of student's speciality, to go for the scientific stream, and gender to males' benefit. The results also showed that Tawjihi (the national examination for high school in Jordan) can predict critical thinking scores among Al-Balqa Applied University students. The difference in critical thinking among students of the scientific and literary streams may refer to the difference in school curricula. The scientific courses focused on critical thinking skills more than the literary ones. Therefore, the researchers recommend the following:

1. Focusing on including critical thinking skills in school curricula where critical thinking skills are very important to an individual's success in studying and in life.

2. There should be a focus on schools' role to develop critical thinking abilities among the literary -stream students as well as to the scientific-stream ones.

3. There should be a focus on families' roles to develop critical thinking abilities among females as well as to males.

4. There should be a focus on designing and applying training programs to develop high critical thinking levels among students with low levels of critical thinking.

5. Further studies should be conducted to investigate the levels and differences in critical thinking in larger samples.

\section{Limitations}

Although the results of this study appeared promising, some limitations must be pointed out. For example, the impossibility of generalizing the results beyond the specific sample of Ajloun University College, Al-Balqa Applied University students used in this study is to be mentioned. Another limitation is that the sample consisted only of Ajloun University College students. Future researchers should use samples that are more widely representative of Al-Balqa Applied University students. Besides, the results of other international studies should also be studied and compared.

\section{Acknowledgment}

Many thanks to all participants who took part in the study and enabled this research to be possible.

\section{REFERENCES}

[1] Zollar, U. (1991). Teaching, learning styles, performance, and students' teaching evaluation in S,T,E,S-focused science teacher education: A quasi-quantitative probe of a case study. Journal of Research in Science Teaching, 28(7), 593 - 603. doi.org,10.1002,tea.3660280705.

[2] Facione, P. (2020). Critical thinking: What it is and what it counts. Retrieved from https: www.insightassessment.com, wp-content,uploads, ia, pdf, whatwhy.pdf.

[3] Brown, M. \& Freeman, K. (2000). Distinguished features of critical thinking classrooms. Teaching in High Education, 5(3), $301-309$.

[4] Ennis, R. (2009). Critical thinking assessment. Theory into Practice. 32(3), 179-186. doi.org,10.1080,00405849309543 594.

[5] Alotaibi, K. (2007). The effect of using some parts of the CORT program in developing critical thinking and improving the level of academic achievement. (Unpublished doctoral dissertation). Umm Al-Qura University, Makkah Al-Mukarramah. KSA.

[6] Algharaibeh, S. (2015). Thinking skills and learning Styles (5th Ed.). Riyadh: Dar Al-Zahra.

[7] Alotaibi, K. (2012). Psychometric properties of Watson Glaser critical thinking appraisal short form (WGCTA SF). Journal of Educational and Islamic Sciences - King Saud University, 24(4), 1427 - 1454.

[8] Brookfield, S. (1997). Assessing critical thinking. New Directions for Adult \& Continuing Education, 75, 17-29. doi.org,10.1002,ace.7502.

[9] Johnson, D. \& Johnson, R. (1988). Critical thinking through structured controversy. Educational Leadership 45, 58-64. Retrieved from https: web.augsburg.edu,erickson,edc490,d ownloads,Critical_Thinking_through_Structured_Controver sy.pdf.

[10] Udall, A. \& Daniels, J. (1991). Creating a thoughtful classroom: strategies to promote student thinking, Grades 3-12. Tucson: Zephyer press. Retrieved From: https:www.amazon.com,Creating-thoughtful-classroom-Str ategies thinking, DP, B0006EY35I.

[11] Facione, N. \& Facione, P. (2008). Critical thinking and 
clinical judgment in the health sciences in An international teaching anthology. The California Academic Press, Millbrae CA. California. Retrieved from https: www.goodreads.com,book,show,3042706-critical-thinkingand-clinical-reasoning-in-the-health-sciences.

[12] Ennis, R. (2011). Critical thinking: reflection and perspective part II. Inquiry: Critical Thinking Across the Disciplines. 26(2), 5-19. DOI: 10.5840, inquiryctnews2011 26215.

[13] Moore, B. \& Parker, R. (2020). Critical thinking (11 $\left.1^{\text {th }} e d.\right)$. California: Mayfield Publishing Company. Retrieved from https: www.amazon.com,Critical-Thinking-Brooke-Noel-M oore,dp,0078119146.

[14] Ennis, R. (1996). Critical thinking dispositions: their nature and assess ability. Informal Logic. 18(2\&3), 165-182. DOI:10.22329, il, v18i2.2378.

[15] Ennis, R. (2001). Argument appraisal strategy: A comprehensive approach. Informal Logic. 21(2), 97-140. doi.org,10.22329,il.v21i2.2240.

[16] Watson, G. \& Glaser, E. (2010). Watson - Glaser TM II critical thinking appraisal technical manual and user's guide. Pearson Education, Inc. Retrieved from https: talentlens.in,wp-content,uploads,2017,07,WG2_TechMan_ v2_r4.pdf.

[17] Elder, Linda \& Paul, R. (2001). Critical thinking: Thinking to some purpose. Journal of Developmental Education, 25(1), 40- 42. Retrieved from https: www.researchgate.net,publication,234603943_

Critical_Thinking_Thinking_to_Some_Purpose.

[18] Aldabbas, K. (2018). Critical thinking skills and its relationship with metacognitive thinking skills among 10th-grade students in Al-Balqa Governorate. Education Journal - Al-Azhar University, (180), 160-205.

[19] Almansour, G. (2017). Critical thinking and its relationship to general (mathematical) reasoning: a field study on a sample of students from the departments of psychology and psychological counseling at the faculty of education at Damascus University. Journal of the Federation of Arab Universities for Education and Psychology, 15(3), 13-54.

[20] Almohadin, S. (2015). The level of critical thinking and its relationship with cognitive motivation among Muta University students. (Unpublished Master's Thesis). Mu'tah University: Jordan.

[21] Hasan, R. (2016). Cognitive load and its relation to critical thinking among university students. Educational and Social Sciences, 22(1), 493 - 534. Retrieved from http: Search.mandumah.com,Record,776283.
[22] Alzoubi, M. \& Sawalmeh, Y. (2017). Constructing a critical thinking skills test by using item response theory. Journal of the Federation of Arab Universities for Education and Psychology, 15(3), 55-92.

[23] Grozdanka, G., Aleksandar, S. \& Aleksandra, G. (2015). Critical thinking of students: An indicator of quality in higher education. Procedia - Social and Behavioral Sciences. 191(2), 591- 596. DOI: 10.1016,j.sbspro.2015.04.501.

[24] Jenkins, Elizabeth (2010). The significant role of critical thinking in predicting auditing students' performance. Journal of Education for Business, 73(5), 274-279. doi.org,10.1080,08832329809601644.

[25] Wise, Mary. (2004). General semantics as critical thinking: A personal view. International listening Association, Centre for Information \& Communication Science, Ball State University, Muncie, In 47306.Retrieved From:https: www.thefreelibrary.com,General+semantics+as+critical+th inking\%3A+a+personal+view.-a0120843378.

[26] Ryan, D. (2014). How critical is critical thinking?. Music Educators Journal, 101(2), 65-70. doi.org10.1177,0027432 114544376.

[27] Onwuegbuzie, A. (2001). Critical thinking skills: A comparison of doctoral and Master - Level student's. College Student Journal, 35(3), 477-480. Retrieved from https:,,go.gale.com,ps, anonymous?id=GALE\%7CA807446 $61 \&$ sid=googleScholar\&v=2.1\&it=r\&linkaccess=abs\&issn $=01463934 \& \mathrm{p}=\mathrm{AONE} \& \mathrm{sw}=\mathrm{w}$.

[28] Alter, C. \& Egan, M. (1997). Logic modelling: A tool for teaching critical thinking in social work practice. Journal of Social Work Education, 33(1), 85-103. doi.org,10.1080,104 37797.1997.10778855.

[29] Temple, C. (2000). What can we learn from (15.000) teachers in central Europe \& Central Asia? Reading teacher, 54(3), 312- 315. Retrieved From https:,,www.jstor.org,stabl e,20204909?seq=1.

[30] Williams R. \& Stockdale, Susan. (2003). High- performing students with low critical thinking skills. The Journal of General Education, 52(3), 200-226. doi.org,10.1353,jge.20 04.0007.

[31] Pablos, P. (2015). Technological solutions for sustainable business practice in Asia. Business Science Reference: USA.

[32] Mare'i, T. \& Nawfal, M. (2007). The level of critical thinking skills among university college of educational sciences (UNRWA) students. Al-Manara, 13(4), 289-342. 